\title{
Penerapan Asas Personalitas Keislaman dalam Permohonan Pengangkatan Anak di Kabupaten Pamekasan
}

\author{
Eka Susylawati \\ (Jurusan Syari'ah STAIN Pamekasan Jln. Raya Panglegur Km. 04 Pamekasan, \\ email: ekasusylawati@gmail.com)
}

\begin{abstract}
Abstrak:
Pengangkatan anak merupakan hal yang lazim dilakukan dalam masyarakat dengan tujuan untuk memperoleh kepastian hukum. Untuk mencapai kepastian hukum tersebut dengan mengajukan permohonan pengangkatan anak ke pengadilan. Hingga saat ini, di Indonesia dalam perkara permohonan anak yang diajukan oleh orang yang beragama Islam, masih mengenal dualisme bidang peradilan yaitu pengadilan agama dan pengadilan negeri. Dalam mengadili dan memutus, kedua lembaga peradilan tersebut mempunyai perbedaan dasar hukum yaitu pengadilan agama mendasarkan pada hukum Islam sedangkan pengadilan negeri mendasarkan pada hukum positif. Dengan demikian, asas personalitas keislaman dalam perkara permohonan pengangkatan anak, belum sepenuhnya berlaku karena orang yang beragama Islam masih dapat mengajukan ke pengadilan negeri. Realita ini juga berlaku di Pamekasan di mana masyarakat lebih familiar mengajukan ke pengadilan negeri.
\end{abstract}

\section{Kata-kata Kunci:}

Penerapan, Personalitas Keislaman, Pengangkatan Anak, Pamekasan

\begin{abstract}
:
Adoption is a common thing to do in the community in order to obtain legal certainty. To achieve the legal certainty to apply to the court for the appointment. Until now, in Indonesia in the case of children the petition filed by people who are Muslims, they know the dualism of the judiciary that religious courts and state courts. In the hear and decide, both the judicial institutions have different legal basis, namely the religious courts based on Islamic law while the court basing on positive law. Thus, the principle of the Islamic personality in the case of application for child adoption, is not yet fully
\end{abstract}


Eka Susylawati

apply for people who are Muslims can still apply to the district court. This reality also applies in Pamekasan where people are more familiar submitted to the district court.

Key Words:

Application, Islamic Personality, Adoption, Pamekasan

\section{Pendahuluan}

Pengangkatan anak merupakan hal yang telah lama lazim dilakukan oleh masyarakat di dunia. Pengaturan pengangkatan anak tersebut berbeda antarnegara, yang disesuaikan dengan kultur dan kebutuhan masyarakatnya. Masyarakat Indonesia masih mengenal pluralisme hukum perdata di mana hukum perdata adat, Islam, dan Barat masih berlaku hingga saat ini sehingga pengaturan hukum pengangkatan anak juga berbeda.

Pasal 1 angka 1 Undang-Undang Nomor 7 Tahun 1989 tentang Peradilan Agama menyatakan bahwa Peradilan Agama adalah peradilan bagi orang-orang yang beragama Islam. Pasal 1 tersebut di atas dipertegas oleh Pasal 2 Undang-Undang Nomor 3 Tahun 2006 tentang Perubahan atas Undang-Undang Nomor 7 Tahun 1989 tentang Peradilan Agama, yang menyatakan bahwa Peradilan Agama adalah salah satu pelaku kekuasaan kehakiman bagi rakyat pencari keadilan yang beragama Islam mengenai perkara tertentu sebagaimana yang dimaksud dalam Undang-Undang.

Salah satu kewenangan peradilan agama berdasarkan Undang-Undang Nomor 3 Tahun 2006 adalah mengadili permohonan asal-usul anak dan pengangkatan anak berdasarkan hukum Islam. ${ }^{1}$ Sebelum berlakunya Undang-Undang tersebut, satu-satunya pengadilan yang berwenang mengadili dan memutus permohonan asal usul dan pengangkatan anak hanya pengadilan negeri. Berlakunya Undang-Undang Nomor 3 Tahun 2006 tidak mencabut kewenangan pengadilan negeri untuk mengadili permohonan pengangkatan anak bagi pemohon yang beragama Islam.

Kedudukan pengadilan negeri dalam mengadili perkara permohonan pengangkatan anak justru diperkuat dalam Buku Pedoman Pelaksanaan Tugas dan Administrasi Pengadilandalam Empat

${ }^{1}$ Musthofa, Pengangkatan Anak Kewenangan Pengadilan Agama, (Jakarta: Sinar Grafika, 2008), 62 
Lingkungan Peradilan. Buku II Edisi 2007 tentang Badan Peradilan Umum yang dikeluarkan oleh Mahkamah Agung, pada alinea 2 angka 7 menyatakan bahwa permohonan pengangkatan anak angkat yang diajukan oleh pemohon beragama Islam dengan maksud untuk memperlakukan anak angkat tersebut sebagai anak kandung dan dapat mewaris maka permohonan diajukan ke pengadilan negeri, sedangkan apabila bertujuan untuk memelihara maka permohonan diajukan ke pengadilan agama. Dengan demikian berdasarkan Pedoman Mahkamah Agung, pemohon yang beragama Islam dapat melakukan pilihan hukum (choice of law) atas kewenangan lembaga peradilan yaitu mengajukan permohonan pengangkatan anak ke pengadilan agama atau ke pengadilan negeri.

Salah satu asas yang berlaku di lingkungan peradilan agama adalah asas personalitas keislaman. Yang dimaksud dengan personalitas keislaman adalah bahwa yang tunduk dan yang dapat ditundukan kepada kekuasaaan peradilan agama adalah mereka yang mengaku dirinya beragama Islam. Idealnya seseorang yang memeluk suatu agama akan mengikuti ajaran agamanya. Seseorang yang beragama Islam mengajukan permohonan pengangkatan anak makapengajuan permohonan semestinya ke pengadilan agama karena putusan pengadilan agama akan mendasarkan pada hukum Islam. Permohonan pengangkatan anak di pengadilan dikategorikan sebagai gugatan voluntair yaitu jenis perkara tanpa sengketa dengan pihak lain. Tujuan dari diajukannya permohonan adalah menyelesaikan kepentingan pemohon tentang suatu permasalahan perdata yang memerlukan kepastian hukum.

Dari sisi kepastian hukum, dua peradilan yang dapat memeriksa dan memutus permohonan pengangkatan anak beridentitas Islam tidaklah menguntungkan bagi masyarakat pencari keadilan karena apabila di belakang hari timbul sengketa waris maka penetapan pengadilan negeri tentang pengangkatan anak, yang menggolongkan anak angkat sebagai ahli waris akan dianulir oleh pengadilan agama. Hal ini dapat menimbulkan ketidakpastian bagi masyarakat akibat dualitas pengadilan ini.

Pada tulisan ini, fokus penelitian mencakup, pertama, bagaimana pandangan hakim Pengadilan Agama dan Pengadilan Negeri Pamekasan dalam penerapan asas personalitas keislaman pada permohonan pengangkatan anak; kedua, apa pertimbangan 
hakim Pengadilan Agama dan Pengadilan Negeri Pamekasan dalam mengabulkan permohonan pengangkatan anak yang diajukan oleh pemohon yang beragama Islam.

\section{Kewenangan Pengadilan Agama dalam Perkara Permohonan Pengangkatan Anak}

Indonesia adalah negara hukum yaitu negara yang penyelenggaraan pemerintahannya didasarkan pada hukum. ${ }^{2}$ Pengadilan agama sebagai salah satu lingkungan peradilan yang ada di Mahkamah Agung, secara yuridis juga diatur dengan undangundang tersendiri yaitu Undang-Undang Nomor 7 Tahun 1989 tentang Peradilan Agama. Undang-Undang (UU) Peradilan Agama memberikan kewenangan absolut kepada pengadilan agama dalam hal menerima, memeriksa, dan memutus perkara antarorang yang beragama Islam

Selain tugas dan fungsi di atas, pengadilan agama memiliki kewenangan absolut yang berbeda dengan badan peradilan lainnya, yaitu: kewenangan dalam bidang perkawinan, bidang kewarisan, wasiat dan hibah. Begitu juga wakaf, sedekah, dan ekonomi syariah. Berdasarkan UU Nomor 3 Tahun 2006 yakni UU tentang Perubahan atas UU Nomor 7 Tahun 1989 tentang Peradilan Agama, dinyatakan bahwa peradilan agama mendapatkan tambahan kewenangan dalam bidang ekonomi syariah, pengangkatan anak dan penetapan asal usul anak. Perluasan kewenangan tersebut sesuai dengan perkembangan hukum dan kebutuhan hukum masyarakat, khususnya masyarakat muslim.

Pengangkatan anak merupakan bagian dari hukum perkawinan sehingga sesuai dengan Pasal 63 UU Nomor 1 Tahun 1974 menyatakan bahwa Pengadilan Agama adalah pengadilan yang berwenang untuk mengadili perkara di bidang hukum perkawinan bagi mereka yang beragama Islam dan peradilan umum bagi yang lainnya sehingga pengangkatan anak yang dilakukan oleh orangorang yang beragama Islam seharusnya menjadi kewenangan pengadilan agama.

Salah satu rujukan dalam pengangkatan anak di kalangan umat Islam didasarkan pada hukum Islam pada Kompilasi Hukum

2Jaenal Aripin, Peradilan Agama Dalam Bingkai Reformasi Hukum di Indonesia, (Jakarta: Prenada Media Group, 2008), 1. 
Islam (KHI). Kompilasi Hukum Islam mengakui eksistensi lembaga pengangkatan anak sebagaimana diatur dalam Pasal 171 huruf h jo. Pasal 209. Kedua pasal tersebut memberi batasan pengertian anak angkat dan akibat hukum terjadinya wasiat wajibah antara anak angkat dan orang tua angkatnya.

Dalam peradilan perdata dikenal dua jenis perkara yaitu gugatan dan permohonan. Gugatan merupakan jenis perkara yang mengandung sengketa dan produk pengadilan yang akan dihasilkan adalah putusan. Sedangkan perkara permohonan adalah perkara non sengketa. Sebagaimana putusan pada umumnya, fundamentum petendi (posita) pada perkara permohonan tidak serumit dibandingkan dalam putusan perkara gugatan (contentiosa). Landasan hukum dan peristiwa yang menjadi dasar permohonan, cukup memuat dan menjelaskan hubungan hukum antara diri pemohon dengan permasalahan hukum yang dipersoalkan. Fundamentum petendi (dalil yang menggambarkan adanya hubungan yang menjadi dasar atau uraian dari suatu tuntutan) permohonan pada prinsipnya didasarkan pada ketentuan pasal undang-undang yang menjadi alasan permohonan.

Oleh karena yang terlibat dalam permohonan hanya sepihak, yaitu pemohon maka pemeriksaan permohonan hanya secara sepihak dan yang hadir di persidangan hanya pemohon atau kuasanya. Proses persidangan bersifat sederhana yaitu hanya mendengar keterangan pemohon atau kuasanya sehubungan dengan permohonan dan memeriksa surat ataupun saksi yang dihadirkan dalam persidangan.

Dalam pemeriksaan perkara permohonan tidak semua asas dalam hukum acara perdata diterapkan. Asas yang harus diterapkan misalnya asas kebebasan peradilan (judicialindependency) yaitu bahwa peradilan tidak boleh dipengaruhi oleh siapapun dan asas peradilan yang adil (fair trial) yaitu bahwa pengadilan tidak diperkenankan bertindak sewenang-wenang. Pemeriksaan juga harus sesuai dengan ketentuan hukum acara yang berlaku (dueprocess of law) serta memberikan kesempatan yang layak pada pemohon untuk membela dan mempertahankan kepentingannya (to give an appropriate opportunity).

Perkara permohonan pengangkatan anak merupakan permohonan sepihak dari pemohon atau kuasanya. Pengajuan permohonan perkara pengangkatan anak pada umumnya diajukan 
oleh masyarakat dengan tujuan memperoleh kepastian hukum. Suatu penetapan waris akan mempunyai nilai apabila menimbulkan adanya status bahwa pemegang tersebut adalah ahli waris sehingga terdapat kepastian hukum.

Adapun prosedur yang harus ditempuh ialah mengajukan surat permohonan pengangkatan anak ke Pengadilan. Hal-hal yang perlu dipersiapkan layaknya sebuah proses permohonan di pengadilan. Bukti-bukti yang dilampirkan misalnya bukti tertulis (surat) berupa akta nikah, akta kelahiran calon anak angkat, surat pernyataan, dan alat bukti yang juga penting, seperti saksi-saksi yang dapat memperkuat dalil-dalil dalam permohonan.

Seperti halnya dalam gugatan, prinsip beracara dan sistem pembuktian, harus ditegakkan dan diterapkan sepenuhnya dalam proses pemeriksaan dan penyelesaian perkara permohonan. Dalam pemeriksaan pembuktian perkara permohonan terdapat hal yang harus ditaati oleh hakim, yaitu:

1. Alat bukti dalam permohonan tidak berbeda dengan alat bukti dalam perkara gugatan. Sesuai dengan Pasal 164 HIR (pasal 284 R.Bg) dan Pasal 1866 KUH Perdata, dalam hukum acara perdata dikenal lima alat bukti yaitu tulisan (akta), keterangan saksi, persangkaan, pengakuan dan sumpah;

2. Untuk pembebanan dalam pembuktian sepenuhnya dibebankan pada pemohon;

3. Nilai pembuktian harus mencapai batas minimal pembuktian. Hakim wajib meminta agar pemohon mengajukan alat bukti yang lain ketika bukti yang diajukan tidak cukup atau tidak bernilai sebagai bukti.

4. Yang sah sebagai alat bukti hanya terbatas pada alat bukti yang memenuhi syarat formil dan materiil.

UU Nomor 3 Tahun 2006 menyatakan bahwa pengadilan agama untuk memberikan penetapan pengangkatan anak berdasarkan hukum Islam. Kewenangan sub bidang perkawinan yaitu penetapan pengangkatan anak berdasarkan hukum Islam dijelaskan dalam Pasal 49 huruf a angka 20. Sedangkan perkaraperkara terkait dengan waris ataupun pembagian harta peninggalan orang tua angkat termasuk dalam bidang hukum waris yang diatur dalam Pasal 49 UU Nomor 3 Tahun 2006. 
Perumusan Pasal 49 UU Nomor 3 Tahun 2006 yang memuat frasa"...antara orang-orang beragama Islam..." menunjukkan bahwa pengadilan berwenang menerima sengketa antara pihak yang satu dengan yang lain yang berlawanan. Penetapan pengangkatan anak tidak bersifat sengketa sehingga kata "antara" dalam kewenangan penetapan pengangkatan anak tidak bermakna terdapat lawan melainkan hanya ada satu pihak yaitu pemohon.

Salah satu upaya untuk menjamin terwujudnya kebebasan kekuasaan Peradilan adalah dengan adanya pembatasan pelaksanaan fungsi peradilan, yang akan tercermin dari pengaturan kompetensi absolut dan kompetensi relatif masing-masing lingkungan peradilan. Dengan pembatasan tersebut maka masing masing akan menjalankan fungsi peradilan sesuai dengan kompetensinya. Penyelesaian sengketa hukum oleh suatu lembaga peradilan yang merdeka merupakan dasar berfungsinya sistem hukum yang baik. UU Peradilan Agama merupakan salah satu peraturan di lingkungan peradilan di Indonesia sebagaimana yang diatur dalam UU Nomor 48 Tahun 2009 tentang Kekuasaan Kehakiman, yang memiliki kewenangan absolut yang berbeda dengan lingkungan peradilan lainnya. Dengan demikian perlu dipertegas kewenangan lembaga peradilan dalam perkara permohonan pengangkatan anak oleh Pemohon yang beragama Islam.

\section{Penerapan Personalitas Keislaman dalam Perkara Permohonan Pengangkatan Anak}

Sebagaimana telah dijelaskan sebelumnya bahwa kewenangan peradilan agama dalam menangani dan memutus perkara berdasarkan pada asas personalitas keislaman. Yang dimaksud dengan personalitas keislaman yaitu bahwa "...yang tunduk dan yang dapat ditundukkan kepada kekuasaan Peradilan Agama, hanya mereka yang mengaku dirinya beragama Islam."3

Asas personalitas keislaman diatur dalam UU Nomor 3 Tahun 2006 Tentang Perubahan atas UU Nomor 7 Tahun 1989 Tentang Peradilan Agama dalam Pasal 2 Penjelasan Umum Alinea Ketiga dan Pasal 49 yang menentukan bahwa asas tersebut terbatas pada perkara-perkara yang menjadi kewenangan absolut peradilan agama.

3M. Yahya Harahap, Hukum Acara Perdata, (Jakarta: Sinar Grafika, 2005), 37. 
Asas personalitas keislaman selaras dengan teori W.C. Van den Berg yaitu receptio in complexu, yang menyatakan bahwa "hukum mengikuti agama yang dianut seseorang sehingga apabila orangnya beragama Islam maka hukum Islam yang berlaku baginya karena orang Islam yang ada di Indonesia telah melakukan resepsi hukum Islam secara keseluruhan."4

Menurut Sudikno Mertokusumo, "ketentuan dalam HIR maupun R.Bg hanya mengatur tentang tata cara mengajukan gugatan, sedangkan tentang persyaratan mengenai isi gugatan tidak diatur." 5 Selanjutnya Pasal 119 HIR/Herziene Indonesische Reglement/Reglemen Indonesia Yang Diperbaharui (Pasal 143 R.bg/Rechtsreglement voor de Buitengewesten/Reglement untuk daerah seberang: Hukum Acara Perdata bagi daerah-daerah luar pulau Jawa dan Madura) memberikan wewenang kepada ketua pengadilan negeri untuk memberi nasihat dan bantuan kepada penggugat dalam mengajukan gugatan sehingga seminimal mungkin dihindari terjadi gugatan yang tidak jelas atau tidak lengkap ketika pemeriksaan persidangan.

Persyaratan mengenai isi gugatan terdapat dalam Pasal $8 \mathrm{Rv}$ yang mengharuskan gugatan pada dasarnya berisi, pertama, identitas para pihak; kedua, dalil-dalil kongkrit tentang adanya hubungan hukum yang merupakan dasar serta alasan-alasan tuntutan (fundamentum petendi); ketiga, tuntutan atau petitum yaitu hal yang dimohon oleh penggugat yang berkait dengan gugatan.

Identitas adalah hal-hal yang berkenaan dengan penggugat dan tergugat yaitu nama dan tempat tinggal ataupun informasi lainnya yang dapat mendukung terhadap kejelasan dari suatu gugatan. Ketentuan mengenai identitas yang diatur dalam Pasal $8 \mathrm{Rv}$ tidak menyebutkan tentang pencantuman agama yang dianut oleh para pihak. Keadaan berbeda yaitu setelah berlakunya UUNomor 1 Tahun 1974 tentang Perkawinan dan UU Nomor 7 Tahun 1989 tentang Peradilan Agama. Pencantuman agama yang dianut sangatlah penting guna menentukan kompetensi lingkungan pengadilan yang berwenang suatu perkara.

${ }^{4}$ Mohammad Daud Ali, Hukum Islam di Peradilan Agama (Kumpulan Tulisan), (Jakarta: Raja GrafindoPersada, 2002), 225.

5Sudikno Mertokusumo, Hukum Acara Perdata Indonesia, (Yogyakarta: Liberty, 1985), 34. 
Pasal 2 ayat (2) UU Nomor 1 Tahun 1974 menyatakan bahwa perkawinan adalah sah apabila dilakukan menurut hukum masingmasing agama dan kepercayaannya. Pasal tersebut diperkuat oleh Pasal 63 ayat (1) yang menyatakan bahwa yang dimaksud dengan pengadilan dalam UU ini: peradilan agama bagi mereka yang beragama Islam dan peradilan umum bagi lainnya.

Di dalam Pasal 1 UU Nomor 7 Tahun 1989 menyatakan bahwa Pengadilan Agama adalah peradilan bagi orang-orang yang beragama Islam. Pengaturan lebih lanjut diatur dalam Pasal 2 yang menyatakan bahwa Pengadilan Agama merupakan salah satu pelaksana kekuasaan kehakiman bagi rakyat pencari keadilan yang beragama Islam mengenai perkara perdata tertentu yang diatur dalam UndangUndang.

Dengan demikian penyebutan agama yang dianut oleh para pihak dalam gugatan ataupun permohonan merupakan keharusan. Tidak ditulisnya agama dalam gugatan ataupun permohonan akan mempengaruhi dalam penyelesaian perkara. Walaupun ketentuan tersebut termasuk dalam bidang hukum formil namun tanpa adanya ketegasan penyebutan agama maka akan dapat mengaburkan kompetensi badan peradilan. Seorang penggugat atau pemohon yang beragama Islam ketika mengajukan perkara permohonan pengangkatan anak ke Pengadilan Negeri maka Pengadilan Negeri akan menerima karena lembaga peradilan ini tidak melihat identitas keislaman penggugat.

Sebagian berpendapat bahwa masih berwenangnya Pengadilan Negeri untuk menerima dan memutus perkara pengangkatan anak Pemohon yang beragama Islam adalah bertitik tolak pada asas hukum perdata yang pada umumnya bersifat mengatur (regelend) dan tidak bersifat memaksa (dwingend). Konsekwensinya perkara pengangkatan anak yang merupakan bagian dari hukum perdata dapat dikesampingkan dengan persetujuan antar pihak yang bersengketa. Aturan hukum yang bersifat mengatur tidak dapat dipaksakan walaupun dengan putusan hakim. Pengajuan pengangkatan anak yang diajukan ke pengadilan termasuk dalam hukum formil. Star Busmann menyatakan bahwa 
"hukum acara perdata pada asasnya bersifat mengikat. ${ }^{6}$ Kekuatan mengikat suatu ketentuan hukum formil telah ditentukan oleh pembuat Undang-Undang.

Letak asas personalitas keislaman berpatokan pada saat terjadinya hubungan hukum artinya patokan menentukan keislaman seseorang didasarkan pada faktor formil tanpa mempersoalkan kualitas keislaman yang bersangkutan. Jika seseorang mengaku beragama Islam, pada dirinya sudah melekat asas personalitas keIslaman. Faktanya dapat ditemukan dari KTP, sensus kependudukan dan surat keterangan lain. Sedangkan mengenai patokan asas personalitas keislaman berdasar saat terjadinya hubungan hukum, ditentukan oleh dua syarat yaitu, pertama, pada saat terjadinya hubungan hukum kedua pihak sama-sama beragama Islam, dan kedua, hubungan hukum yang melandasi keperdataan tertentu tersebut berdasarkan hukum Islam sehingga cara penyelesaiannya berdasarkan hukum Islam.

Dalam menentukan patokan asas personalitas keislaman yang nantinya pada diri seseorang melekat asas personalitas keislaman dengan melihat beberapa kriteria sebagai berikut:

1. Pengakuan yaitu cukup dengan pengakuan secara lisan tanpa melihat kualitas keislaman seseorang atau bukti apakah orang tersebut benar melaksanakan ajaran Islam atau tidak;

2. Identitas

Dengan melihat kartu identitas yang dimiliki seseorang seperti halnya KTP, SIM, dan kartu identitas lainnya yang menyatakan agama Islam.

3. Amalan

Dengan melihat cara beribadah yang sesuai dengan ajaran Islam dan juga perbuatan yang dilakukan adalah berdasarkan hukum Islam, maka pada dirinya melekat asas personalitas keislaman.

4. Kesaksian

Dengan melihat beberapa bukti bahwa adanya indikasi seseorang tersebut beragama Islam, dan juga mendengar dari

\footnotetext{
6 Starr Busman, Mr. C.M. Hoofstukken van Burgerlijke Rechtvoeredering, Harleem, de Erven F Bohn, 1984, 18 dalam Sudikno Mertokusumo, Hukum Acara Perdata Indonesia (Yogyakarta: Liberty, 1985), 6.
} 
kesaksian seseorang lain bahwa seseorang tersebut beragama Islam.

Apabila salah satu ciri di atas telah terpenuhi maka pada diri seseorang telah melekat asas personalitas keislaman dan otomatis perkara yang diajukan oleh orang yang mempunyai kriteria minimal salah satu dari yang telah disebutkan di atas dalam mengajukan perkara dapat diterima di Pengadilan Agama. Jangkauan kewenangan mengadili permohonan pengangkatan anak ditinjau dari segi hukum Islam dapat dilihat melalui pendekatan ketentuan Pasal 49 ayat 3 Undang-Undang Nomor 3 Tahun 2006.

\section{Hasil Penelitian}

Putusan pengadilan merupakan keseluruhan rangkaian proses pemeriksaan pesidangan sampai pada sikap hakim untuk mengakhiri perkara yang disidangkan. Hakim harus berpikir secara yuridis, sistematis dan teratur sehingga setiap persoalan hukum dapat dipecahkan secara baik dan benar sehingga putusannya dapat diterima secara yuridis, sosiologis dan filosofis. ${ }^{7}$ Selain memutus berdasarkan hukum, hakim juga harus memperhatikan kebenaran dan keadilan. ${ }^{8}$

Hakim dalam pernyelesaian perkara melalui proses perdata berkewajiban melaksanakan fungsi peradilan yang diberikan oleh undang-undang untuk menegakkan kebenaran dan keadilan. Untuk mencapai hal tersebut hakim harus mempertahankan tata hukum perdata sesuai dengan perkara yang disengketakan dengan acuan:

a. Menetapkan pasal dan peraturan perundang-undangan hukum materiil mana yang akan diterapkan dalam perkara tersebut. Dalam mempertahankan tata hukum perdata hakim sedapat mungkin berpatokan dan mengunggulkan (prevail) ketentuan peraturan perundangan hukum positif yang ada dan dalam perkara tertentu hakim mencari dan menerapkan nilai-nilai perdata materiil yang hidup dalam masyarakat sesuai dengan nilai-nilai kepatutan dan kemanusiaan sehingga dapat diwujudkan penyelesaian sengketa yang berwawasan

7Purwanto S Gandasubrata, Tugas Hakim Indonesia, (Jakarta: Bina Yustisia, Litbang MARI, Jakarta, 1994), 17

8Ibid. 
dan bernuansa moral justice dan tidak sekedar keadilan menurut hukum (legal justice).

b. Berdasarkan penemuan ketentuan hukum materiil itu hakim dapat menjadikannya sebagai landasan dan alasan untuk menetapkan pihak yang berperkara yang lebih utama dan lebih sempurna memiliki kebenaran berdasarkan sistem hukum pembuktian. ${ }^{9}$

Semua yang ada dalam putusan merupakan satu kesatuan dan saling terkait sehingga tidak dapat dipisahkan. ${ }^{10}$ Secara garis besar suatu putusan terdiri dari empat bagian yaitu kepala putusan, identitas para pihak, pertimbangan (consideran) dan diktum (amar). ${ }^{11}$ Jika putusan pengadilan merupakan mahkota bagi hakim dan yang merupakan inti mahkota adalah pertimbangan hukum karena merupakan pertanggungjawaban hakim terhadap putusannya.

Pertimbangan hukum terdiri dari dua bagian yaitu pertimbangan duduk perkara atau peristiwa atau fakta dan pertimbangan tentang hukumnya. Pertimbangan duduk perkara atau peristiwanya memuat fakta-fakta hukum selama persidangan di Pengadilan. Esensi pertimbangan tentang fakta yaitu menguraikan hasil pembuktian sehingga diperoleh petunjuk dan membimbing pada pembentukan keyakinan hakim. Fakta yang terungkap di persidangan terkadang menimbulkan perbedaan pendapat diantara pihak-pihak yang berperkara. Pertimbangan hukum memuat alasanalasan atau argumentasi hukum serta penalaran hukum yang dilakukan oleh hakim.

Menurut Djokosoetono, putusan hakim yang baik harus dapat memenuhi dua persyarat yaitu kebutuhan teoritis dan praktis.12 Kebutuhan teoritis melihat pada isi putusan beserta pertim bangannya. Kebutuhan teoritis ini lebih pada pertanggungjawaban dari segi hukum. Sedangkan kebutuhan praktis artinya bahwa suatu putusan diharapkan dapat menyelesaikan sengketa hukum yang ada dan dapat diterima oleh para pihak maupun masyarakat.

${ }_{9}$ M Yahya Harahap, Hukum Acara Perdata, 70.

${ }^{10}$ Abdullah, Pertimbangan Hukum Putusan Pengadilan, (Surabaya: Bina Offset Surabaya, 2008), 11

11Sudikno Mertokusumo, Penemuan Hukum, (Yogyakarta : Liberty, 2001), 168.

12Purwanto S Gandasubrata, Tugas Hakim..,17. 
Sebagaimana halnya putusan hakim pada umumnya dalam penetapan permohonan pengangkatan anak juga haruslah terdapat pertimbangan-pertimbangan. Pertimbangan dalam permohonan pengangkatan anak didasarkan pada bukti-bukti yang diajukan dalam persidangan. Bukti-bukti tertulis ataupun pengakuan dari pemohon harus pula didukung dengan saksi-saksi yang mengetahui secara sungguh-sungguh tentang keadaan orang tua kandung, orang tua angkat, dan anak angkat. Semua alat bukti diperkuat dengan keterangan dari pemohon tentang motivasi, keinginan dan kesungguhan dari orang angkat dalam rangka pengangkatan anak.

Semua dalil-dalil dan bukti-bukti yang dihadirkan oleh pemohon dalam perkara permohonan pengangkatan anak akan dijadikan bahan oleh hakim dalam membuat pertimbangan hukum. Dalam pertimbangan hukum akan diuraikan secara sistematis dalildalil dan alat bukti yang dikemukakan selama persidangan. Apabila dalam persidangan permohonan pengangkatan anak tidak melanggar hukum/peraturan perundang-undangan yang berlaku dan dalil-dalil yang dikemukakan oleh pemohon terbukti maka pengadilan akan mengabulkan permohonan pengangkatan anak.

Sebagaimana telah dijelaskan sebelumnya bahwa setelah berlakunya Undang-Undang Nomor 3 Tahun 2006 tentang Perubahan Atas Undang-Undang Nomor 7 Tahun 1989 tentang Peradilan Agama, Peradilan Agama berwenang mengadili perkara permohonan pengangkatan anak. Perkara permohonan pengangkatan anak merupakan kewenangan baru bagi pengadilan agama. Kewenangan Peradilan Agama dalam perkara permohonan pengangkatan anak dibenarkan oleh Rofiah, yang menyatakan bahwa sejak tahun 2006 yaitu sejak diberikannya kewenangan pengadilan agama dalam perkara pengangkatan anak orang Islam, pengadilan agama Pamekasan telah memutus. Kuantitasnya semakin tahun semakin meningkat. Hal ini nampak dari rekapitulasi jumlah perkara pengangkatan anak. ${ }^{13}$

Pada sisi yang lain, Pengadilan Negeri Pamekasan juga berwenang untuk mengadili perkara pengangkatan anak. Kewenangan tersebut dimiliki oleh Pengadilan Negeri jauh sebelum

13 Rofi'ah, Wakil Panitera Pengadilan Agama Pamekasan, Wawancara tanggal 3 Oktober 2016 
kewenangan peradilan agama. Masyarakat Pamekasan lebih familier dalam mengajukan pengangkatan anak di pengadilan negeri. Pengadilan Negeri Pamekasan sebagai salah satu dari bagian dari peradilan umum mengadili perkara dari masyarakat pada umumnya termasuk dalam perkara permohonan pengangkatan anak. Berdasarkan hasil wawancara dengan dengan Sujarwo Darmadi, yang menyatakan bahwa dalam perkara pengangkatan anak, Pengadilan Negeri Pamekasan hingga saat ini berwenang mengadili karena tidak adanya aturan yang melarang pengadilan negeri untuk mengadili. Alasan pemohon mengajukan penetapan pengangkatan anak ke pengadilan negeri adalah karena tidak memiliki anak atau diperlukan untuk memperoleh tunjangan anak pada daftar gaji. ${ }^{14}$ Alasan lain yaitu karena pengadilan negeri adalah bagian dari peradilan umum yang menurut undang-undang berwenang memeriksa dan memutus perkara masyarakat pada umumnya sehingga dalam menerima perkara tidak melihat pada agama yang dianut Pemohon. ${ }^{15}$

Salah satu syarat dari gugatan atau permohonan ke pengadilan adalah identitas dari pihak-pihak. Identitas pemohon yang biasanya tertera dalam permohonan adalah nama, alamat, pekerjaan, umur ataupun agama pemohon. Pengajuan gugatan ataupun permohonan ke pengadilan negeri pada umumnya tidak dicantumkan agama pemohon. Hal ini berbeda dengan permohonan penetapan pengangkatan anak yang diajukan ke pengadilan agama, sebagaimana pernyataan berikut: Salah satu asas dalam hukum acara di pengadilan agama adalah asas personalitas keislaman artinya pengadilan agama menangani perkara-perkara tertentu antar orang yang beragama Islam sebagaimana kewenangan yang diberikan oleh Undang-Undang. Dalam gugatan atau permohonan ke pengadilan agama harus agama dicantumkan sehingga hakim pada persidangan yang pertama dapat menilai apakah perkara yang diajukan merupakan kewenangan pengadilan agama. Idealnya pengadilan negeri juga menerapkan ini sehingga apabila suatu perkara menjadi kewenangan pengadilan agama maka pengadilan negeri akan

\footnotetext{
14 Sujarwo Darmadi, Panitera Muda Bagian Hukum Perdata Pengadilan Negeri Pamekasan, wawancara tanggal 24 September 2016 15 Ibid.
} 
menolak atau memberikan saran agar mengajukan ke pengadilan agama. 16

Dari hasil wawancara dengan beberapa pemohon beragama Islam, yang pernah mengajukan permohonan pengangkatan anak ke pengadilan negeri memberikan alasan yang berbeda ketika ditanyakan mengapa mengajukan ke pengadilan negeri dan bukan ke pengadilan agama. Sebagian pemohon tidak mengetahui bahwa pengadilan agama mempunyai kewenangan, ada yang beranggapan bahwa tidak ada perbedaan apakah permohonan pengangkatan anak dilakukan di pengadilan negeri atau di pengadilan agama karena yang dipentingkan adalah legalitas dan sebagian yang lain karena berkeinginan untuk menjadikan anak angkat sebagaimana layaknya anak kandung serta memberikan warisan kepada anak angkat. Pada umumnya pemohon tidak mengetahui perbedaan konsekuensi hukum pengangkatan anak yang dilakukan di pengadilan negeri dan pengadilan agama.

Perbedaan akibat hukum pengangkatan anak di pengadilan negeri dan pengadilan agama berbeda terutama dalam hubungan antara anak, orang tua kandung dan orang tua angkat, sebagaimana pernyataan berikut: "Pengangkatan anak di Pengadilan Negeri mendasarkan pada hukum Barat (adopsi). Konsekuensi penetapan pengangkatan anak adalah memutus hubungan keperdataan antara orang tua kandung. Akibatnya anak hanyalah mempunyai hubungan keperdataan dengan orang tua angkat dan hanya akan memperoleh waris dari orang tua angkat."17

Berbeda dengan pengangkatan anak di pengadilan agama mendasarkan pada hukum Islam. Dalam hukum Islam hubungan nasab antara anak dan orang tua tidak dapat diputuskan oleh apapun, termasuk walaupun diangkat anak oleh orang lain. Tugas dari orang tua angkat adalah memberikan penghidupan, pemeliharaan dan pendidikan. Karena hubungan dengan orang tua kandung tidak terputus maka anak angkat akan tetap memperoleh warisan dari orang tua kandung. Sedangkan dari orang tua

${ }^{16}$ H. Mudiahidin AR, M.Hum, Ketua Pengadilan Agama Pamekasan, wawancara tanggal 11 Oktober 2016

17Tito Eliandi, SH. MH, Hakim Pengadilan Negeri Pamekasan, wawancara tanggal 24 September 2006 
angkatnya akan memperoleh wasiat wajibah yaitu maksimal 1/3 dari harta peninggalan. 18

Hakim pengadilan negeri dan pengadilan agama karena dasar yang hukum yang dipergunakan berbeda yaitu hukum Islam di pengadilan agama dan hukum Barat di pengadilan negeri maka pertimbangan hakim dari kedua pengadilan tersebut juga berbeda sebagaimana pernyataan berikut "Tugas hakim adalah menjalankan isi perundangan-undangan baik dalam mengadili maupun dalam memutus perkara. Pertimbangan hakim Pengadilan Agama dalam mengadili perkara permohonan pengangkatan anak orang yang beragama Islam, yang pertama; karena pengadilan masih berwenang sebagaimana peraturan pemerintah di atas dan walaupun pengadilan agama juga berwenang mengadili tetapi hingga saat ini belum ada satu aturan pun yang menghapus kewenangan Pengadilan Negeri tersebut. Yang kedua; karena pemohon mengajukan ke Pengadilan Negeri sehingga hakim akan memutus sesuai dengan peraturan perundang-undangan yang mengatur tentang anak angkat. Ketiga: orang tua angkat secara materiil mempunyai kemampuan untuk membiayai anak yang diangkat."19

Dari sisi hukum acara pemeriksaan perkara permohonan pengangkatan anak di pengadilan negeri dan pengadilan agama memiliki kesamaan, yaitu dimulai dari tahap pengajuan di pengadilan, pemeriksaan dan putusan. Perbedaan hanya pada sisi hukum materiil yang digunakan. Pertimbangan hukum dalam mengabulkan permohonan pengangkatan anak pada dasarnya tidak jauh berbeda antara pengadilan agama dan pengadilan negeri sebagaimana wawancara berikut: "Hakim dalam memeriksa, mengadili dan kemudian mengabulkan permohonan pengangkatan anak mendasarkan pada bukti-bukti selama persidangan. Yang tidak kalah pentingnya adalah menanyakan agama orang tua kandung. Apabila pemohon dan orang kandung beragama Islam merupakan jalan pembuka utama bagi pengadilan untuk mengabulkan permohonan." 20

Pertimbangan pengadilan negeri dalam mengabulkan permohonan pengangkatan anak akan mendasarkan pada fakta-fakta

18Drs. Ikhsan, Hakim Pengadilan Agama Pamekasan, wawancara tanggal 4 Oktober 2016

19Tito Eliandi, SH. MH, Hakim Pengadilan Negeri Pamekasan, wawancara tanggal 24 September 2006

20Ibid. 
selama persidangan antara lain: kesediaan orang tua angkat untuk menjadikan anak angkat sebagaimana anak kandung dan adanya surat pernyataan dari orang tua kandung untuk melepaskan anaknya. Surat pernyataan tersebut merupakan bukti bahwa orang tua kandung tidak akan mengambil anaknya di belakang hari. Tujuan dari surat pernyataan itu adalah memastikan bahwa orang tua kandung merelakan anaknya untuk dipelihara oleh orang lain. ${ }^{21}$

Berkait dengan asas hukum adalah lex specialis derogat legi generalis yang artinya bahwa hukum aturan yang bersifat khusus mengalahkan aturan yang bersifat umum. Kewenangan badan peradilan apabila dikaitkan dengan permohonan pengangkatan anak, pengadilan agama merupakan badan peradilan yang bersifat khusus, yaitu khusus mengadili perkara orang yang beragama Islam. Sedangkan pengadilan negeri adalah peradilan yang bersifat umum sehingga tidak membedakan agama dari pemohon. Berdasarkan asas lex specialli derogate lex generali maka pengadilan agama sebagai pengadilan yang bersifat khusus mengalahkan kewenangan pengadilan negeri untuk memeriksa dan memutus permohonan pengangkatan anak yang diajukan pemohon yang beragama Islam

\section{Kesimpulan}

Pandangan hakim pengadilan agama dan pengadilan negeri Pamekasan dalam penerapan asas personalitas keislaman pada permohonan pengangkatan anak adalah berbeda. Hakim Pengadilan Agama Pamekasan memiliki pandangan bahwa penerapan asas personalitas keislaman pada permohonan pengangkatan anak yang diajukan oleh orang yang beragama Islam merupakan kewenangan peradilan agama sedangkan hakim pengadilan negeri menilai bahwa dalam perkara pengangkatan anak masih mengenal dualisme kewenangan pengadilan karena belum ada aturan perundangundangan yang melarang menerima perkara permohonan pengangkatan anak oleh pemohon yang beragama Islam.

Pertimbangan hakim pengadilan agama dan pengadilan negeri dalam mengabulkan permohonan pengangkatan anak tidak

21Tito Eliandi, SH. MH, Hakim Pengadilan Negeri Pamekasan, wawancara tanggal 24 September 2006 
memiliki perbedaan yang signifikan, yaitu ingin mendapatkan kepastian hukum. Sedangkan perbedaannya adalah di pengadilan negeri terdapat surat pernyataan yang menerangkan bahwa anak angkat telah diserahkan kepada pemohon dan telah disepakati tidak akan diambil lagi dari pemohon di kemudian hari.

Akibat hukum adanya penetapan Pengadilan Agama dan Pengadilan Negeri Pamekasan terhadap status anak angkat adalah berbeda. Pengangkatan anak di Pengadilan Agama didasarkan pada hukum Islam yakni didasarkan pada kepentingan anak angkat dalam hal pemeliharaan dan pendidikan dan tidak memutuskan hubungan anak dengan orang tua kandungnya sehingga anak angkat tetap memiliki nasab dengan orang tua kandung. Sedangkan pengangkatan anak di pengadilan negeri didasarkan pada hukum Barat sehingga hubungan kekerabatan dengan orang tua kandungnya terputus dan anak angkat akan statusnya sama dengan anak kandung. Penetapan pengangkatan anak di pengadilan negeri tidak akan menimbulkan masalah di kemudian hari selama semua ahli waris dari orang tua angkat tidak keberatan atas kedudukan anak angkat yang memperoleh warisan dari orang tua angkatnya.

\section{Daftar Pustaka}

Abdullah, Pertimbangan Hukum Putusan Pengadilan. Surabaya, Bina Offset Surabaya, 2008.

Alam, Andi Syamsu dan M Fauzan, Hukum Pengangkatan Anak Perspektif Islam. Jakarta, Kencana, 2008.

Ali, Mohammad Daud, Hukum Islam di Peradilan Agama (Kumpulan Tulisan). Jakarta, Raja GrafindoPersada, 2002.

Arikunto, Suharsimi, Prosedur Penelitian Suatu Pendekatan Praktik. Jakarta, Rineka Cipta, 1996.

Aripin, Jaenal, Peradilan Agama Dalam Bingkai Reformasi Hukum di Indonesia. Jakarta, Prenada Media Group, 2008.

Dimyati M, Penelitian Kualitatif : Paradigma, Epistimologi, Pendekatan Merode dan Terapan. Malang : IPTI dan PPS UM, 2000.

Freidman, Lawrence M, American Law: An Introduction. New York, WW Norton \& Company, 1998.

Gandasubrata, Purwanto S, Tugas Hakim Indonesia. Jakarta, Bina Yustisia, Litbang MARI, Jakarta, 1994. 
Hadjon, Phillipus M dan Titiek Sri Djatmiati, Argumentasi Hukum .Yogyakarta, Gadjah Mada Press, 2005.

Harahap, M. Yahya Harahap, Hukum Acara Perdata, Jakarta, Sinar Grafika, 2005.

Kamil, Ahmad dan M. Fauzan, Hukum Perlindungan dan Pengangkatan Anak di Indonesia. Jakarta, Rajawali Press, 2010.

M Djojodiguno dan R. Tirtawinata dalam Irma Setyowati Soemitro, Aspek Hukum Perlindungan Anak, Semarang, Bumi Aksara, 1990.

Manan, Bagir. StrategiPengembanganPeradilan Agama, Makalah, PPHIM danDepartemen Agama, Jakarta, tanggal 8 Desember 1989

Melilia, Djaja S., Pengangkatan Anak (Adopsi) di Indonesia, Bandung, Tarsito, 1982.

Mertokusumo, Sudikno. Hukum Acara Perdata Indonesia, Yogyakarta, Liberty, 1985.

Moleong, Lexy, Metodologi Penelitian Kualitatif, Bandung, Remaja Rosdakarya, 1990.

Musthofa. Pengangkatan Anak Kewenangan Pengadilan Agama, Jakarta, Sinar Grafika, 2008.

Pandika, Rusli, Hukum Pengangkatan Anak, Jakarta, Sinar Grafika, 2012.

Rahardjo, Satjipto, PermasalahanHukum di Indonesia, Bandung, Alumni, 1983.

Setyowati, Irma Soemitro, Aspek Hukum Perlindungan Anak, Semarang, Bumi Aksara, 1990.

Soekamto, Soerjono, Pengantar Penelitian Hukum, Jakarta, Universitas Indonesia Press, 2004.

Suriasmantri, Jujun S., Filsafat Ilmu Sebuah Pengantar Populer, Jakarta, Pustaka Sinar Harapan, 2000.

Wignjodipuro, Surojo, Asas-asas Hukum Adat, Jakarta, Kinta, 1972.

Tim Penyusun, Kamus Besar Bahasa Indonesia (KBBI), Jakarta, Balai Pustaka, 1976.

Warsito, Hermawan, Pengantar Motodologi Penelitian .Jakarta, Gramedia Pustaka Utama, 1993.

Wigjosoebroto, Soetandyo, Hukum: Paradigama Metode dan Dinamika Masalahnya. Jakarta, Elsam dan Huma, 2002.

Zaini, Muderis, Adopsi Suatu Tinjauan dari Tiga Sistem Hukum, Jakarta, Sinar Grafika, 2006). 